\title{
Urgences
}

\section{Encres folles et souvenirs marins}

\section{Sophie Lemieux}

Numéro 15, octobre 1986

Épigraphiques

URI : https://id.erudit.org/iderudit/025293ar

DOI : https://doi.org/10.7202/025293ar

Aller au sommaire du numéro

Éditeur(s)

Urgences

ISSN

0226-9554 (imprimé)

1927-3924 (numérique)

Découvrir la revue

Citer ce document

Lemieux, S. (1986). Encres folles et souvenirs marins. Urgences, (15), 25-25.

https://doi.org/10.7202/025293ar d'utilisation que vous pouvez consulter en ligne.

https://apropos.erudit.org/fr/usagers/politique-dutilisation/ 


\section{Sophie Lemieux ENCRES FOLLES ET SOUVENIRS MARINS}

nobody, not even the rain, has such small hands

e.e. cummings: "somewhere i have never travelled."

Quand je parle de toi, j'ai des hippocampes qui galopent sur ma langue. De tout petits hippocampes qui s'affolent un peu à l'idée de ton nom. Leurs pas résonnent toujours dans l'écho de mes mots, sans sabots.

Nu pieds, comme toi, agitant les orteils dans l'eau salée l'eau vive où tu barbottes joyeusement. Impérieusement.

Et je sais, oui, dans la fumée d'automne je sais que tu essaies en cachette mon violoncelle. Tes doigts d'étoiles filantes sont trop verts pour l'archet: les notes que tu proposes marchent sur la queue des chats!

N'as-tu pas d'oreille?

Malgré tout, je me laisse porter, emporter par tes rêves, vols d'outardes et souffles de dragon. Mes pingouins moqueurs, la louve et mon gros lion jouent aux dés avec tes gros-becs et ton savant colimaçon.

J'aime que nos bestiaires se rencontrent sur le même chemin.

J'aime, mais aussi je crains ta démesure qui soudain m'envahit. Dehors, encres folles, encres douces et souvenirs marins: la mer est noire, ce soir, d'avoir avalé la nuit. 